\title{
Development of a new deformation-controlled rockbolt: numerical modelling and laboratory verification
}

Y Yokota Kajima Technical Research Institute Singapore, Singapore

Z Zhao Nanyang Technological University, Singapore

W Nie Nanyang Technological University, Singapore

K Date Kajima Technical Research Institute Singapore, Singapore

K Iwano Kajima Technical Research Institute, Japan

Y Koizumi Kajima Technical Research Institute, Japan

Y Okada Kajima Technical Research Institute, Japan

\begin{abstract}
To prevent large tunnel deformations caused by rock bursts or squeezing ground conditions, rockbolts need to satisfy both strength capacity and the required deformability. Currently, energy-absorbing rockbolts, such as the cone bolt and the D-bolt, have been successfully used in deep mining to avoid sudden tunnel collapses. This paper proposes a new energy-absorbing rockbolt, referred to as a deformation-controlled rockbolt (DC-bolt). The performance of the proposed DC-bolt was verified by numerical simulations using discontinuous deformation analysis (DDA) and by prototype laboratory tests. As a result, it is concluded that the DC-bolt possesses both high loading capacity and deformation capacity. Additionally, the DC-bolt can limit rock surface movement when it reaches a certain displacement. Thus, it can be a useful tunnel support for tunnels that are to be excavated in squeezing ground conditions.
\end{abstract}

Keywords: energy-absorbing rockbolt, deformation-controlled rockbolt, pull-out test, DDA

\section{Introduction}

Over the last few decades, conventional tunnelling methods (i.e. the new Austrian tunnelling method, the drill and blasting tunnelling method) have frequently been used in the construction of tunnels/caverns under severe geological conditions (e.g. high overburden, extremely shallow tunnel cover, non-symmetrical earth pressure/anisotropic stress conditions and large cross-sections). As a result, the role of tunnel support (i.e. rockbolts, steel sets and sprayed concrete) has become more critical. Furthermore, in the case of tunnelling under extremely high overburden, it is necessary to use the rockbolt appropriately to prevent significant rock deformation caused by rock bursts or squeezing (Figure 1).

In conventional rockbolt design, the bolt's strength capacity is the main consideration, and the rockbolts are expected to resist loading and displacement rigidly during/after the excavation. However, in order to deal with large deformations caused by rock bursts or squeezing ground, it is necessary to consider not only the bolt's strength capacity but also its deformability. By allowing and controlling deformation of the ground, the ground pressure acting on the support material, such as rockbolts, can be reduced, whereby the failure of support materials can be prevented (Hoek 2006). 


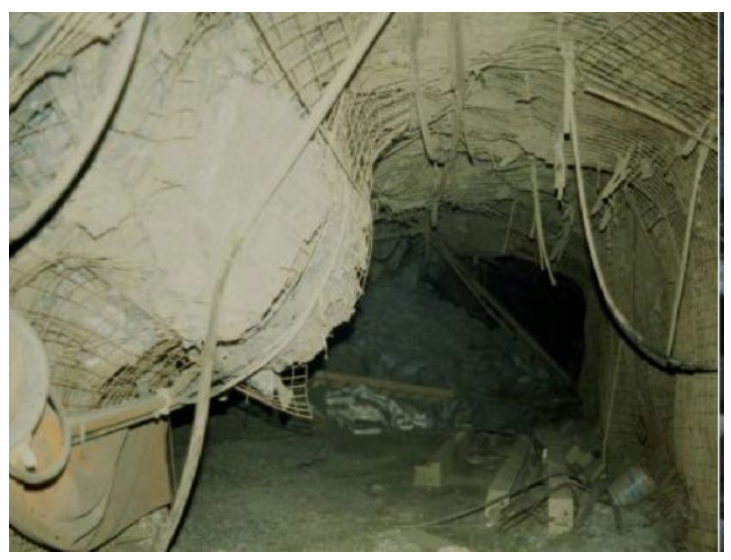

(a)

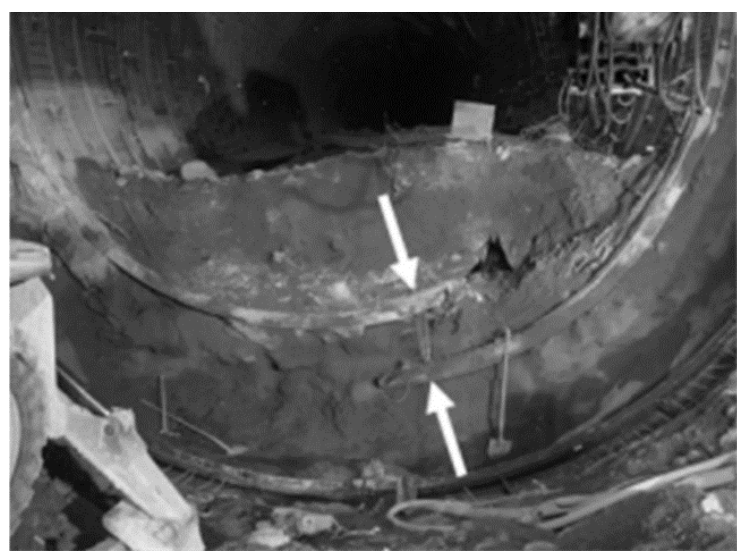

(b)

Figure 1 (a) Support system damaged by rockburst (Kaiser \& Cai 2013); (b) Sheared-off steel arch caused by squeezing behaviour (Rehbock-Sander \& Jesel 2018)

Meanwhile, for countermeasures against squeezing ground in civil engineering tunnels, several yielding supports have been developed, such as the yielding steel set with a sliding mechanism, high deformable concrete and lining stress controllers (Arno et al. 2006; Barla 2001; Hoek 2006; Schubert \& Moritz 1998). For rockbolting, cone bolts and D-bolts have also been employed to deal with squeezing deformations in the field of deep mining (Li 2011). However, in civil engineering tunnels, fully grouted rockbolts are still widely used, even under squeezing conditions (Fabbri 2004). Li (2017) concluded that the current rockbolting system for squeezing behaviour in civil engineering tunnels is incompatible with the other tunnel support methods used-that is, the steel sets and the sprayed concrete provide ductile support, but the rockbolts provide non-ductile support. Thus, there is a need to develop/apply a type of energy-absorbing rockbolt with ductile characteristics.

In this paper, the authors propose a new energy-absorbing rockbolt that has both a high loading capacity and a large deformation capacity, and it can ultimately control rock displacement. In other words, it allows large deformation but limits the rock movement when it reaches a certain amount of displacement. Controlling the final deformation probably makes it easier to use an energy-absorbing rockbolt for civil engineering tunnelling where the final excavated and supported tunnel shape is generally more critical than that of tunnels in mining projects. By modelling the new rockbolt with discontinuous deformation analysis (DDA) and carrying out laboratory testing for its verification, it is possible to understand the reinforcing effects of the new rockbolt quantitatively. The newly developed energy-absorbing rockbolt is referred to as a deformation-controlled rockbolt (DC-bolt).

\section{$2 \quad$ Laboratory pull-out tests with prototypes}

Three-metre DC-bolts were manufactured, as shown in Figure 2, and laboratory pull-out tests were carried out. Test cases and specifications of the rockbolts are listed in Table 1. For comparison purposes, the result of a fully grouted rockbolt, which was pulled-out in a construction site, is also shown in Figure 2. Two DC-bolts with distances of $30 \mathrm{~mm}$ and $100 \mathrm{~mm}$ between the anchor and the ring were prepared. The boreholes were reproduced with steel pipes $(\phi=50 \mathrm{~mm}$ ) and filled with mortar (UCS = approximately $10 \mathrm{MPa}$ ). After the appropriate mortar strength was confirmed, the pull-out force was applied by a centrehole jack. Figure 3 shows a photo of the laboratory pull-out test setup. During the pull-out tests, the pullout load and the displacement of the rockbolt head were monitored by a load cell and two displacement metres attached to the edge of the rockbolt. 

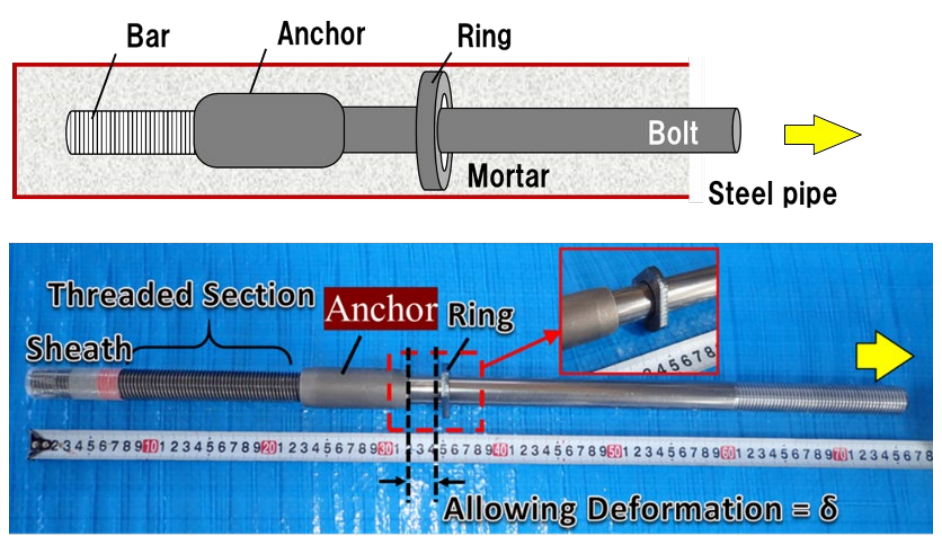

Figure 2 Prototype of DC-bolt: schematic view and photograph

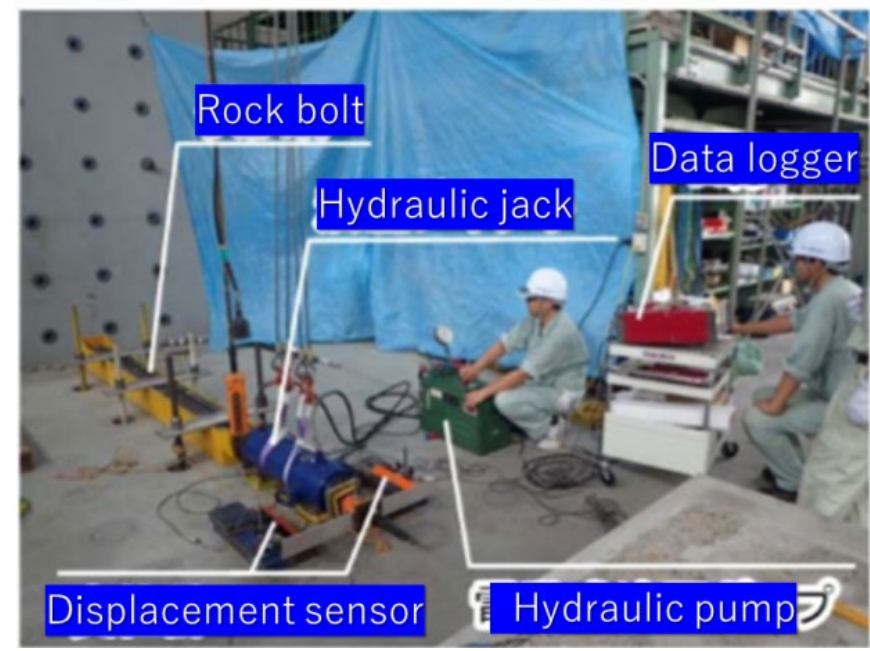

Figure 3 Laboratory pull-out test condition

Table 1 Test cases and specifications of the rockbolt

\begin{tabular}{llllll}
\hline Case & Bolt type & Bolt length & Thread length & $\begin{array}{l}\text { Allowable } \\
\text { displacement }\end{array}$ & Mortar strength \\
\hline 1 & Fully grouted rockbolt & $3 \mathrm{~m}$ & $3,000 \mathrm{~mm}$ & - & $10 \mathrm{MPa}$ \\
2 & $\begin{array}{l}\text { Deformation-controlled } \\
\text { rockbolt }\end{array}$ & $3 \mathrm{~m}$ & $205 \mathrm{~mm}$ & $30 \mathrm{~mm}$ & $10 \mathrm{MPa}$ \\
3 & $\begin{array}{l}\text { Deformation-controlled } \\
\text { rockbolt }\end{array}$ & $3 \mathrm{~m}$ & $205 \mathrm{~mm}$ & $100 \mathrm{~mm}$ & $10 \mathrm{MPa}$ \\
\hline
\end{tabular}

Figure 4 shows the load-displacement curves obtained from the pull-out tests for the fully grouted rockbolts and for the two DC-bolts. In the case of the fully grouted rockbolt, the pull-out force started climbing linearly until the pull-out force approached the tensile strength of the steel bar (450 MPa); the test was then stopped to prevent the rockbolt from rupturing. At $200 \mathrm{kN}$ of pull-out loading, the displacement of the rockbolt head was only $5 \mathrm{~mm}$. In contrast, for the newly developed DC-bolt, a tri-linear-shaped load-displacement curve can be observed in both cases. To be specific, both curves increased linearly until reaching $100 \mathrm{kN}$ of pull-out loading (i.e. primary resisting section). At this point, the horizontal displacement was approximately $10 \mathrm{~mm}$; therefore, the slopes of both load-displacement curves were slightly smaller than for the fully grouted rockbolt. This is because that the DC-bolt resisted the pull-out force only at the far end of the rockbolt, as shown in Figure 5, whereby the extension of the smooth bar between the collar and the anchor of the rockbolt was induced. After a pull-out loading of $100 \mathrm{kN}$, both 
load-displacement curves showed transition points and flattened out (deformable section), and load-displacement curves showed the second transition points at around $30 \mathrm{~mm}$ and $100 \mathrm{~mm}$ of horizontal displacement, respectively. Afterwards, the two curves gradually increased again, indicating that the ring of DC-bolts started to resist against the pull-out force after the anchor contacting to the ring (second resisting section). The slopes of the two load-displacement curves after the second transition points were almost equal. When the rings were broken at $200 \mathrm{kN}$ of pull-out force, the displacement at the rockbolt head was $60 \mathrm{~mm}$ and $135 \mathrm{~mm}$ respectively. Since the displacement of the fully grouted rockbolt was $5 \mathrm{~mm}$, we could verify the advantage of the newly developed DC-bolt against the large tunnel displacement.

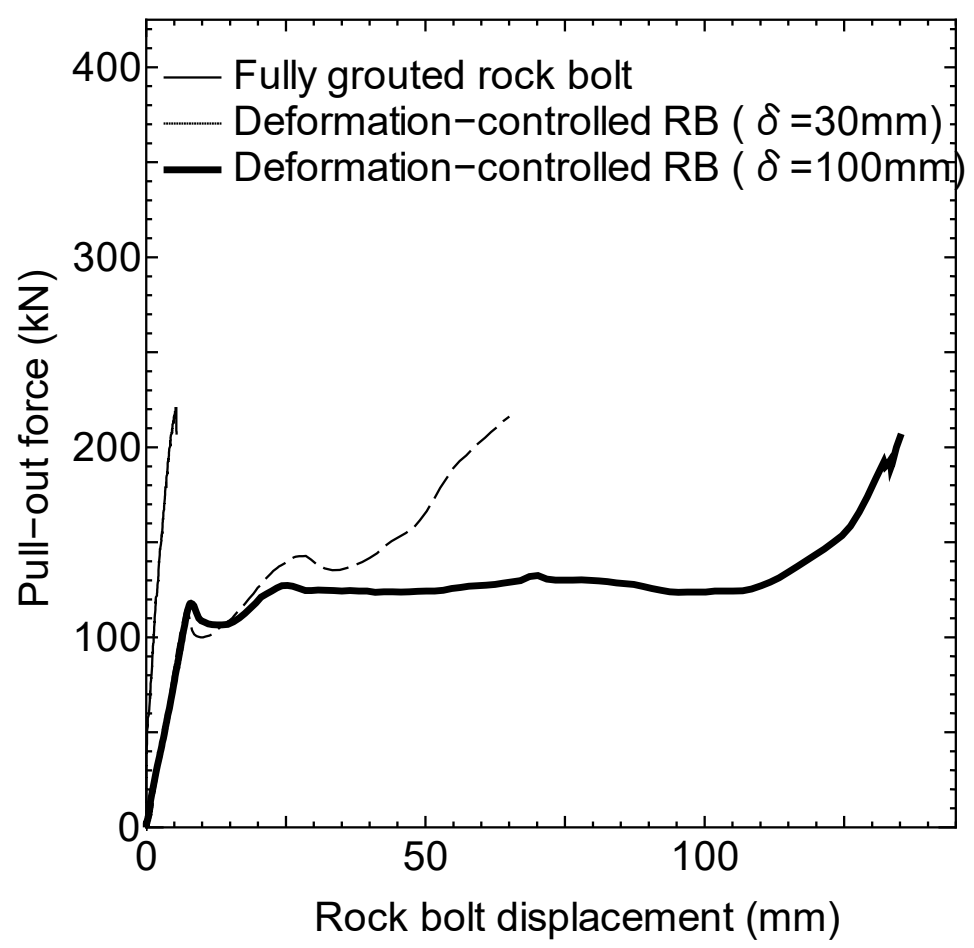

Figure 4 Load-displacement curves obtained

(1) Primary resistance along the bolt-mortar interface (mainly threaded bar)

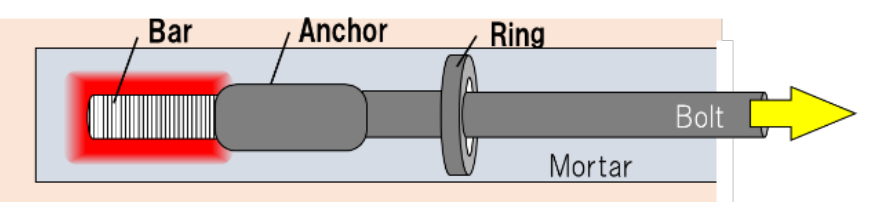

(2) Deformable section by the anchor ploughing inside the mortar

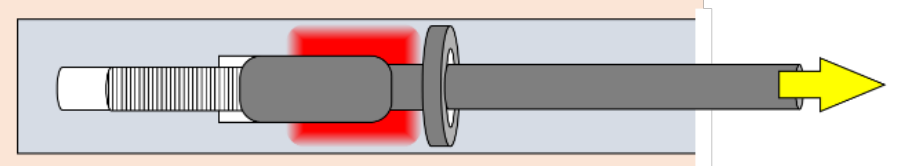

(3) Secondly resistance at the ring

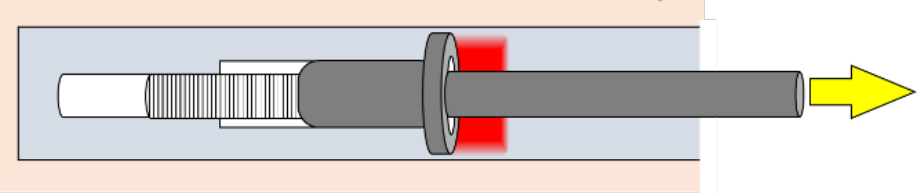

Figure 5 Supporting mechanism of DC-bolt from laboratory pull-out tests 


\section{Simulation of pull-out test with DDA}

The behaviour of the DC-bolt was modelled by incorporating a unique tri-linear bond-slip model under the framework of the DDA model as shown in Figure 6. The proposed tri-linear bond-slip model can be expressed by:

$$
\tau=k \cdot s+c
$$

where:

$\tau=$ the shear stress at the bolt-grout interface.

$s \quad=$ the relative displacement between the bolt and the rock.

The shear force on the bolt-grout interface $F_{s}$ for a unit length can be expressed by:

$$
F_{s}=\pi \cdot D \cdot \tau=\pi \cdot D \cdot k \cdot s+\pi \cdot D \cdot c
$$

where:

$D \quad=$ the diameter of rockbolt.

The parameters $k$ and $c$ are defined for each of the three stages (i.e. Stages I, II, III as shown in Figure 6) as follows:

$$
\begin{gathered}
\text { when } 0 \leq s \leq s_{1}: k=k_{1}=\frac{\tau_{1}}{s_{1}} ; \mathrm{c}=c_{1}=0 . \\
\text { when } s_{1} \leq s \leq s_{2}: k=k_{2}=\frac{\tau_{2}-\tau_{1}}{s_{2}-s_{1}} ; \mathrm{c}=c_{2}=\frac{\tau_{1} \cdot s_{2}-\tau_{2} \cdot s_{1}}{s_{2}-s_{1}} \\
\text { when } s>s_{2}: k=k_{3}=\frac{\tau_{3}-\tau_{2}}{s_{3}-s_{2}} ; \mathrm{c}=c_{3}=\frac{\tau_{2} \cdot s_{3}-\tau_{3} \cdot s_{2}}{s_{3}-s_{2}}
\end{gathered}
$$

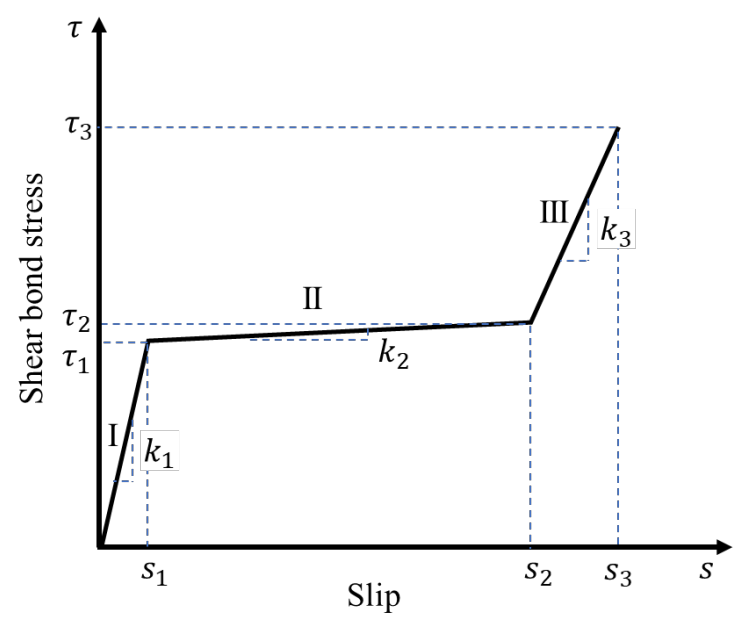

Figure 6 Incorporated a special tri-linear bond-slip model with DDA

Figure 7 shows the DDA simulation model of the pull-out test with the $3 \mathrm{~m}$ length rockbolt. The pull-out force was applied to the head of the rockbolt with a loading rate of $10 \mathrm{kN} / \mathrm{s}$. For comparison purposes, both the DC-bolts and the fully grouted rockbolt were simulated as shown in Figure 8, and the corresponding simulation cases and model parameters are listed in Tables 2 and 3. For the DC-bolt, two different deformation allowances were considered (i.e. $30 \mathrm{~mm}$ and $100 \mathrm{~mm}$ ). The tensile strength of the rockbolts was set to $450 \mathrm{MPa}$.

The shear force and the axial force distribution during pull-out simulations are shown in Figures 9 and 10, and the load-displacement curves are summarised in Figure 11. In the case of the fully grouted rockbolt, the shear force was generated from the collar of the rockbolt, and it became smaller with the increase of rockbolt length. The axial force distribution showed similar trends to the shear force distribution-namely, 
the maximum axial force was observed at the collar of the rockbolt, and it reduced with the increase in depth of the rockbolt. These results are quite consistent with typical pull-out test results for fully grouted rockbolts (Farmer 1975). After the pull-out load reached $270 \mathrm{kN}$, the shear force around the collar of the rockbolt started to decrease, which was probably due to debonding failure along the bolt-grout interface. In the case of the DC-bolt, the shear force was generated only at the far end of the rockbolt, and the shear force distribution was found to be entirely different from that of the fully grouted rockbolt. This is because the bolt-grout interface between the rockbolt collar and the anchor was set to weak friction compared with that of the fully grouted rockbolt. The axial force distribution was also found to be different from that of the fully grouted rockbolt, but it was confirmed to follow the typical distribution of an end anchor rockbolt.

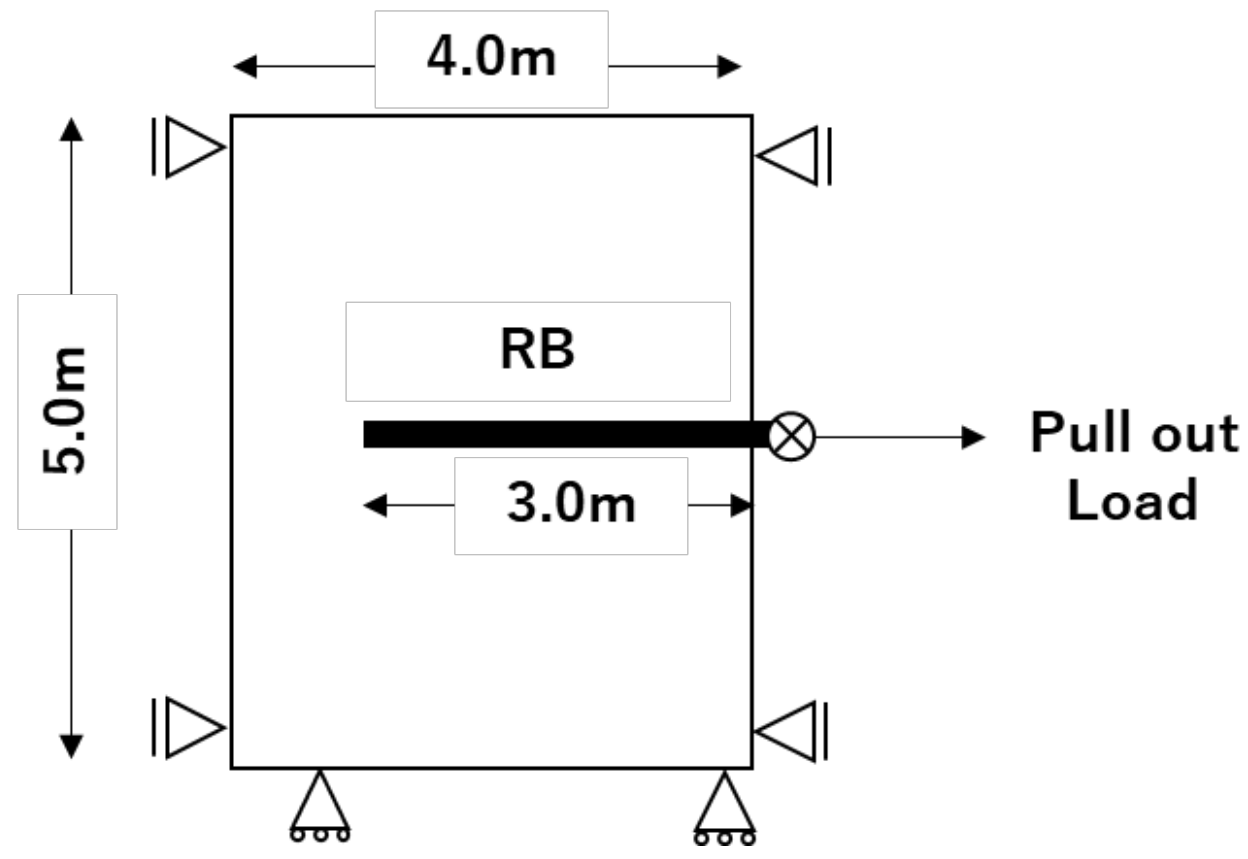

Figure 7 DDA simulation model of the pull-out test

\section{Fully grouted rock bolt}

Schematic view

DDA model (11 nodes)

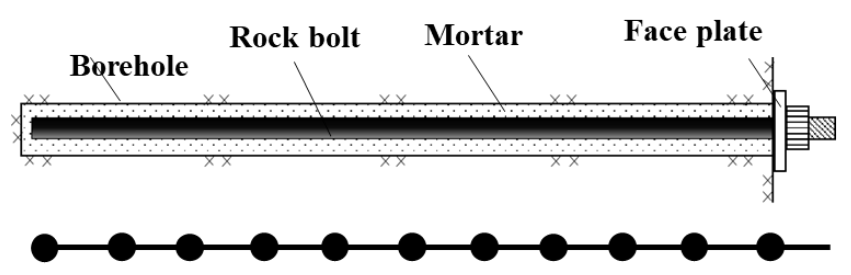

: Fixed node

\section{Deformation-controlled rock bolt}

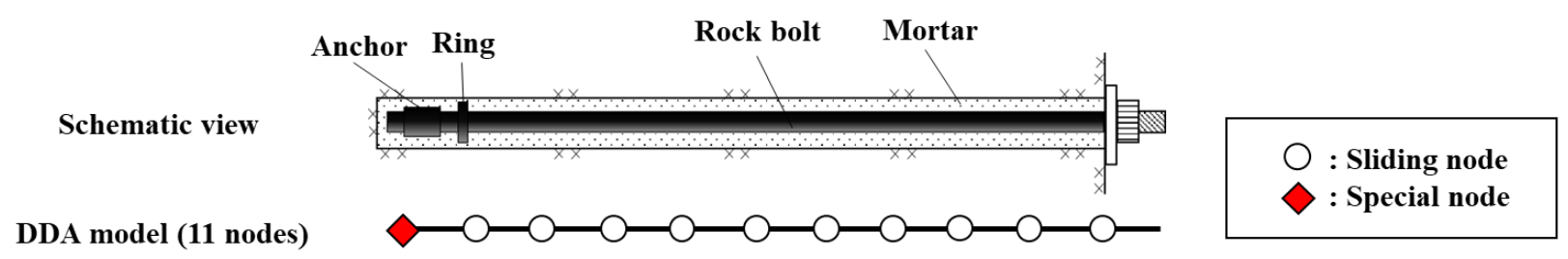

Figure 8 DDA rockbolt model for the pull-out test simulation 
Table 2 DDA simulation cases (pull-out test model)

\begin{tabular}{llll}
\hline Case & Bolt type & Bolt length & Allowable displacement $(\mathbf{m m})$ \\
\hline 1 & Fully grouted rockbolt & $3 \mathrm{~m}$ & - \\
2 & Deformation-controlled rockbolt & $3 \mathrm{~m}$ & 30 \\
3 & Deformation-controlled rockbolt & $3 \mathrm{~m}$ & 100 \\
\hline
\end{tabular}

Table 3 Rockbolt specifications (pull-out test model)

\begin{tabular}{llllll}
\hline Item & Parameters & Value & Item & Parameters & Value \\
\hline & 30 & \multirow{2}{*}{ Bolt } & Yield strength $(\mathrm{MPa})$ & 450 \\
& 200 & & Extreme strain $(\%)$ & 24 \\
& $4.0 \mathrm{e} 9$ & & $\mathrm{k} 1(\mathrm{~Pa} / \mathrm{m})$ & $3.8 \mathrm{e} 8$ \\
$\mathrm{k} 2(\mathrm{~Pa} / \mathrm{m})$ & $-4.0 \mathrm{e} 9$ & $\mathrm{k} 2(\mathrm{~Pa} / \mathrm{m})$ Case 2 -Case 3 & $1.7 \mathrm{e} 6 / 5.2 \mathrm{e} 5$ \\
$\mathrm{k} 3(\mathrm{~Pa} / \mathrm{m})$ & 1.0 & Special node & $\mathrm{k} 3(\mathrm{~Pa} / \mathrm{m})$ & $3.8 \mathrm{e} 8$ \\
$\tau 1(\mathrm{kN} / \mathrm{m})$ & $1.0 \mathrm{e} 6$ & & $\tau 1(\mathrm{kN} / \mathrm{m})$ & $0.56 \mathrm{e} 6$ \\
$\tau 2(\mathrm{kN} / \mathrm{m})$ & $0.5 \mathrm{e} 6$ & & $\tau 2(\mathrm{kN} / \mathrm{m})$ & $0.61 \mathrm{e} 6$ \\
\hline
\end{tabular}

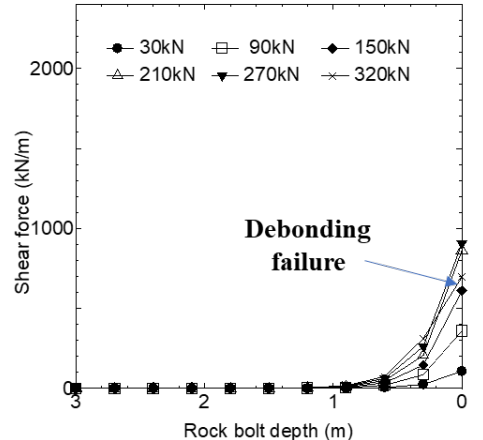

(a)

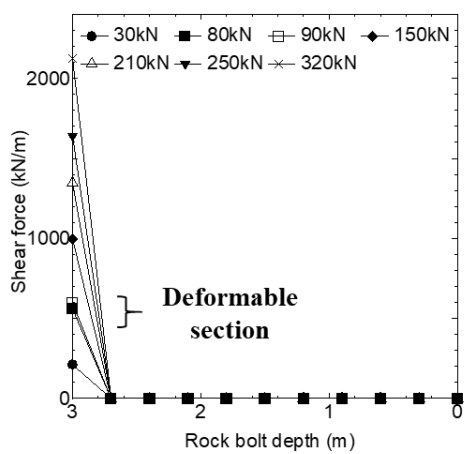

(b)

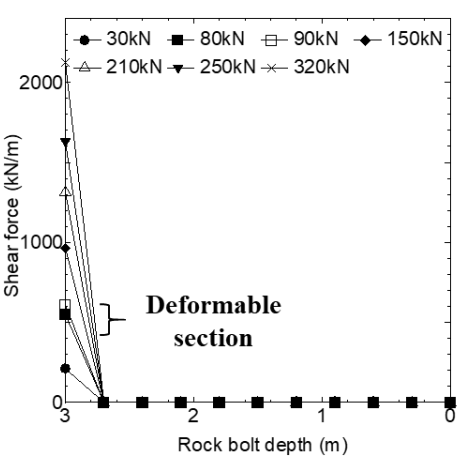

(c)

Figure 9 Shear force distribution during DDA pull-out simulations: (a) fully grouted rockbolt; (b) DC-bolt ( $\delta=30 \mathrm{~mm})$; (c) DC-bolt $(\delta=100 \mathrm{~mm})$

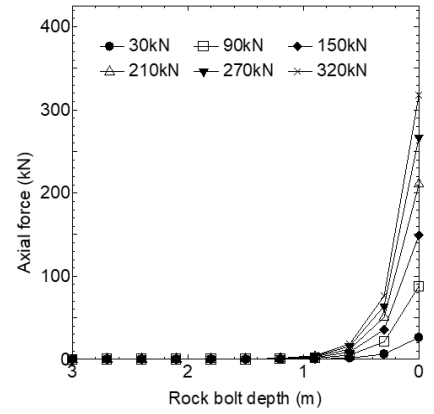

(a)

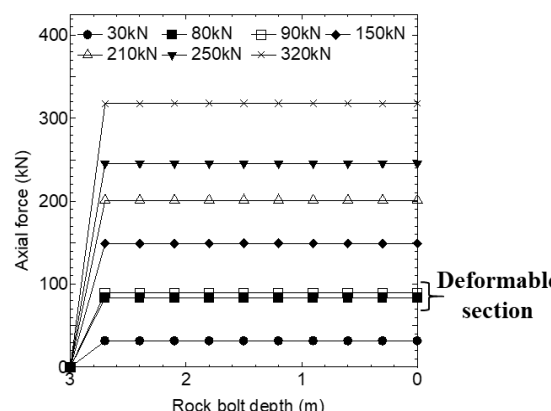

(b)

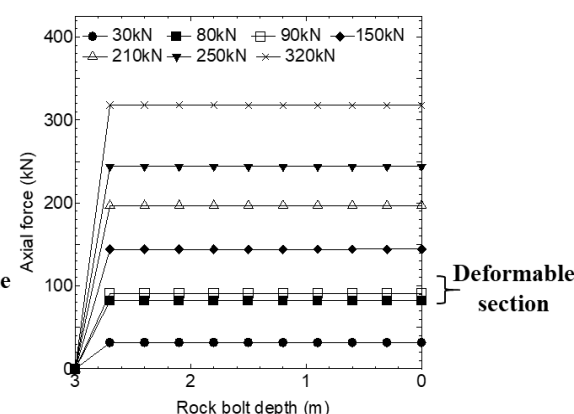

(c)

Figure 10 Axial force distribution during DDA pull-out simulations: (a) fully grouted rockbolt; (b) DC-bolt ( $\delta=30 \mathrm{~mm})$; (c) DC-bolt $(\delta=100 \mathrm{~mm})$ 


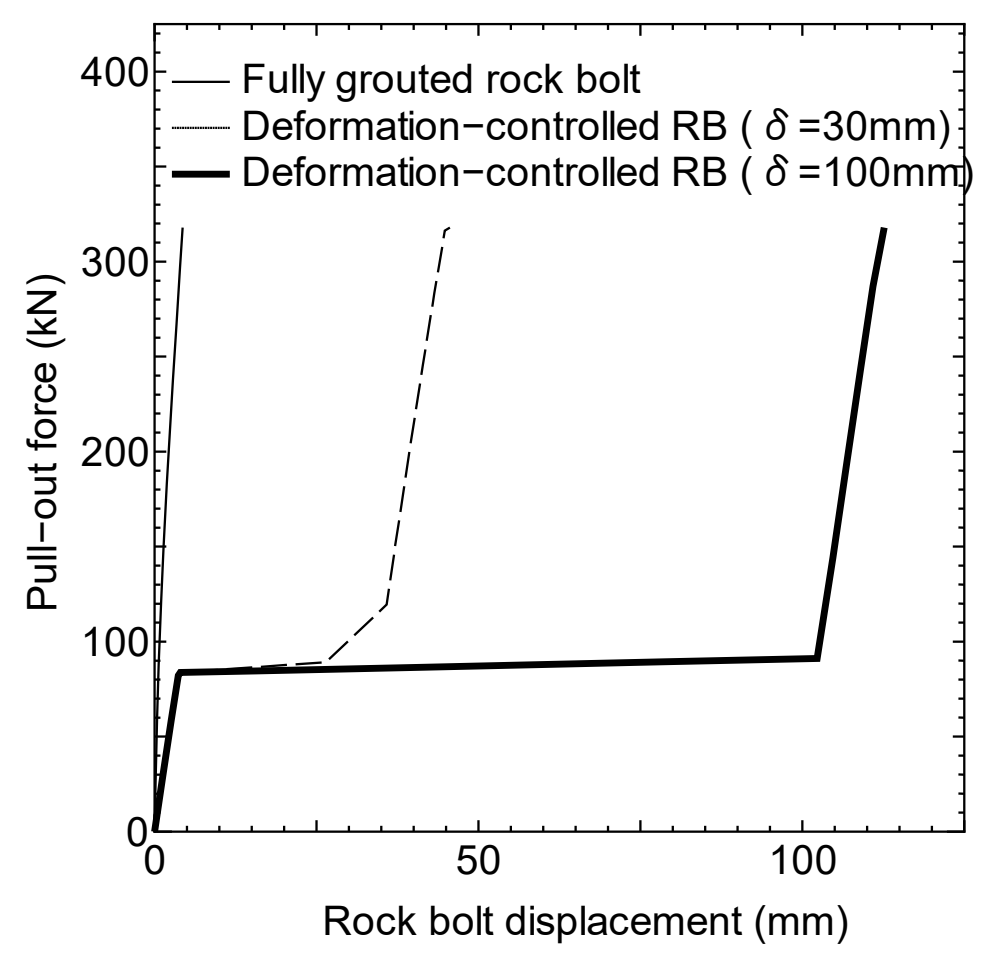

Figure 11 Load-displacement curves obtained from DDA pull-out simulations

The simulated load-displacement curves clearly show the different characteristics of each rockbolt. Specifically, the load-displacement curve of the fully grouted rockbolt shows a linear relationship between the pull-out force and the displacement of the rockbolt head until the rockbolt failed due to tension. The bolt stiffness in extension shown by the gradient of the graph is higher than that of the DC-bolts. Therefore, it can be concluded that the fully grouted rockbolt can be a suitable support element when the tunnel displacement has to be constrained. However, it should be noted that a tensile failure may occur when a large deformation occurs in a tunnel supported using fully grouted rockbolts.

In contrast, both load-displacement curves of the DC-bolts show the tri-linear relationship between the pull-out force and displacement at the rockbolt head. The pull-out force increased linearly until it reached the first transition point. After that, both curves showed a plateau. After the second transition point (i.e. $30 \mathrm{~mm}$ or $100 \mathrm{~mm}$ respectively), the curves started to rise sharply again. It is noted that the DC-bolt can sustain a large deformation without failure; thus, it can provide effective support under squeezing ground conditions. Furthermore, it can be used for various types of displacement control by adjusting the amount of the deformation allowance.

The results obtained from the DDA pull-out simulations (Figure 11) are consistent with the results obtained from the laboratory pull-out tests (Figure 4). The DC-bolts can be designed to suit various geological conditions (i.e. the amount of deformation allowance; the number of rockbolts).

\section{$4 \quad$ Tunnel excavation simulated by the DDA-based DC-bolts}

Figure 12 shows a simulation model for a tunnel excavation in a rock mass that has two joint sets. The tunnel cover was $1.5 \mathrm{~W}$, where $\mathrm{W}$ is the tunnel width. The in situ stresses in the vertical and horizontal directions in the model were set to $2.4 \mathrm{MPa}$ and $4.8 \mathrm{MPa}$, respectively. The rock mass properties are listed in Table 4. The parameters of the rockbolts modelled were the same as those used in the simulation of pull-out tests, with the deformation allowance for the DC-bolts set to $100 \mathrm{~mm}$. In order to evaluate the effect of DC-bolts only, the steel set and the sprayed concrete were not employed in this study. After simulating the tunnel excavation, the shear stress distribution, the axial force distribution of every rockbolt and rockbolt displacements were evaluated. 


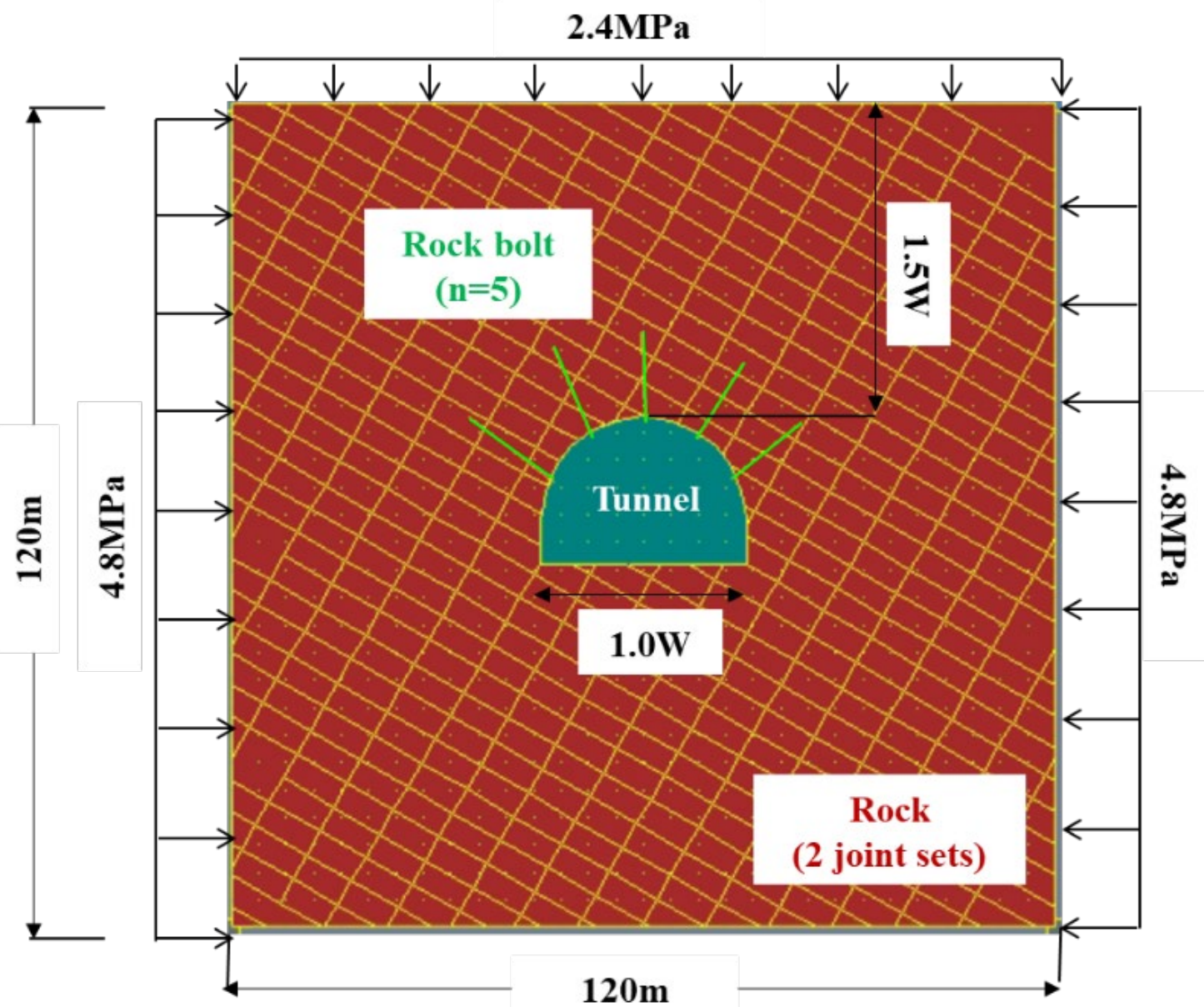

Figure 12 DDA simulation model for the tunnel excavation

Table 4 Rock mass properties

\begin{tabular}{|c|c|c|c|c|c|c|c|c|}
\hline Item & Properties & Value & Item & Properties & Value & Item & Properties & Value \\
\hline \multirow{3}{*}{ Rock } & Density $\left(\mathrm{kg} / \mathrm{m}^{3}\right)$ & 2,600 & Joint & $\begin{array}{l}\text { Friction angle } \\
\left({ }^{\circ}\right)\end{array}$ & 30 & Joint & $\begin{array}{l}\text { Cohesion } \\
\text { (MPa) }\end{array}$ & 2 \\
\hline & Poisson ratio & 0.2 & \multirow{2}{*}{$\begin{array}{l}\text { Joint } \\
\text { set } 1\end{array}$} & Dip angle $\left({ }^{\circ}\right)$ & 60 & \multirow{2}{*}{$\begin{array}{l}\text { Joint } \\
\text { set } 2\end{array}$} & Dip angle $\left({ }^{\circ}\right)$ & -30 \\
\hline & $\begin{array}{l}\text { Elastic modulus } \\
\text { (GPa) }\end{array}$ & 50 & & Spacing $(m)$ & 8 & & Spacing (m) & 4 \\
\hline
\end{tabular}

Figures 13 and 14 show the simulation results with fully grouted rockbolts and the DC-bolts respectively. The principal stress, the vertical stress distribution and the shear force distribution along the rockbolts are illustrated in Figure 13. Additionally, the axial force distribution along the rockbolt is shown in Figure 14. For the fully grouted rockbolts, three out of five rockbolts ruptured during tunnel excavation. For the two rockbolts that did not fail, a shear force was generated at each discontinuity perpendicular to the rockbolt axis. In contrast, the DC-bolts did not rupture and successfully withstood the large deformation due to excavation. Moreover, observed shear forces and axial force distributions were consistent with those of pull-out test simulations. In other words, the shear force was generated only at the far end of the rockbolt, and the axial force was distributed uniformly along the length of the rockbolt. From the vertical stress distribution, the excavation disturbed zone with fully grouted rockbolts could be seen to be slightly wider than that with the DC-bolts because of the rupture of three rockbolts during the excavation. It is also noteworthy that the axial force of the new DC-bolt was more than $100 \mathrm{kN}$, and the rockbolt displacement was more than $100 \mathrm{~mm}$. This means the DC-bolt had already experienced its deformable section (second 
stage shown in Figure 5) and had started to resist tunnel deformation again (third stage shown in Figure 5). Currently, a used energy-absorbing rockbolt cannot restrict the tunnel deformation in this manner after large deformation has occurred unless new rigid rockbolts are additionally installed, which will not be effective because of the additional cost and time.

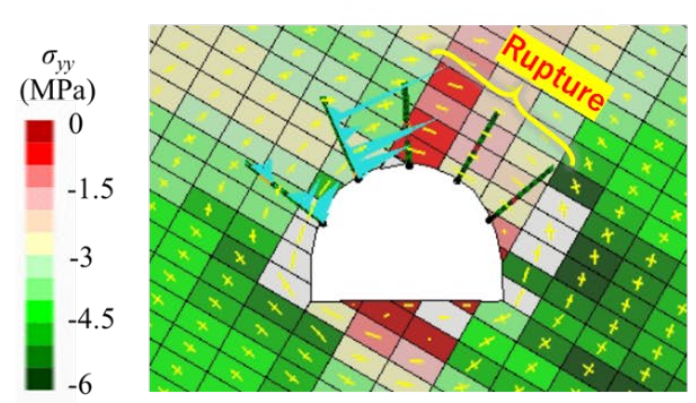

(a)

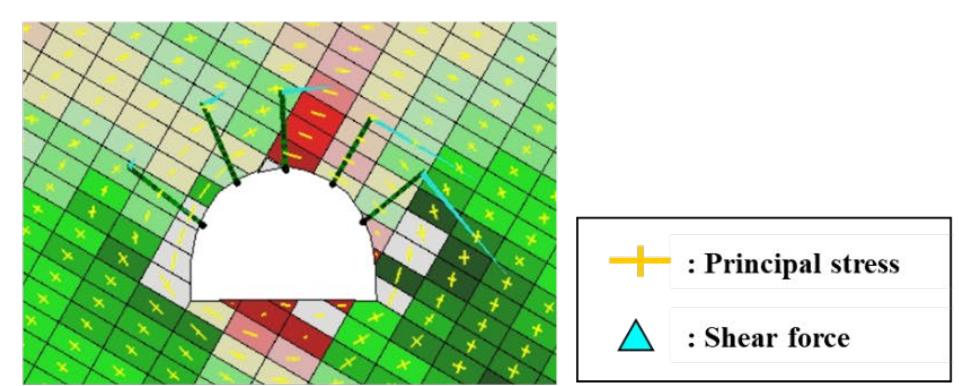

(b)

Figure 13 Shear force distribution after the excavation: (a) fully grouted rockbolt; (b) deformation-controlled rockbolt

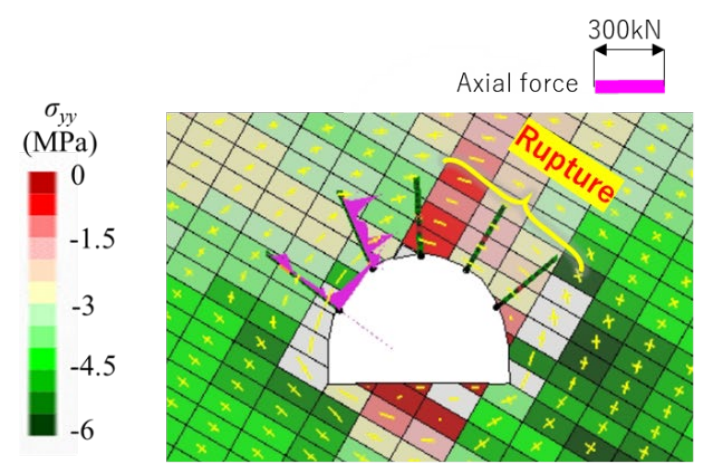

(a)

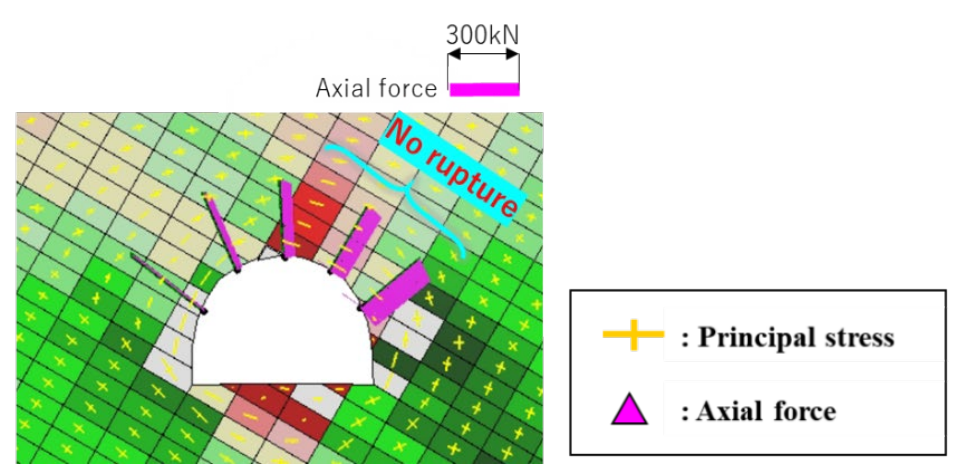

(b)

Figure 14 Axial force distribution after the excavation: (a) Fully grouted rockbolt; (b) Deformation-controlled rockbolt

Figure 15 shows the monitoring locations and the rock displacement after the excavation. As shown in Figure 15a, the monitoring locations from (1) to (3) correspond to the location where the fully grouted rockbolts failed in tension. Additionally, the tunnel surface displacement with DC-bolts was smaller than that with the fully grouted rockbolts in these locations. This result demonstrates the advantage of the DC-bolt under a severe condition where large tunnel displacements occur. Conversely, for monitoring points (4) and (5) where no rockbolts were ruptured-including both the fully grouted rockbolt and DCbolt-the rock displacement with fully grouted rockbolts was smaller than that with DC-bolts. This means it is important to select the right rockbolts (e.g. fully grouted rockbolts or DC-bolts) for the right applications. 


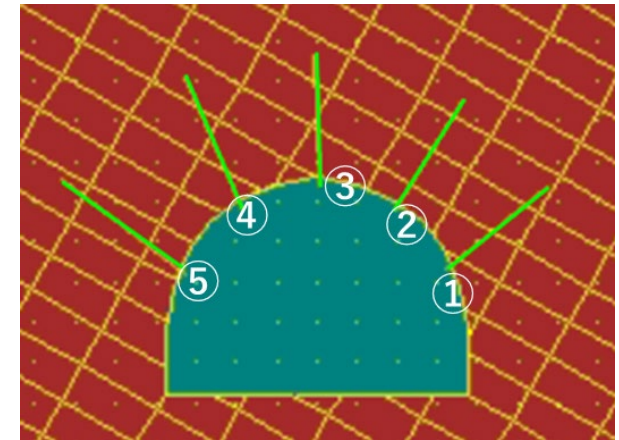

(a)

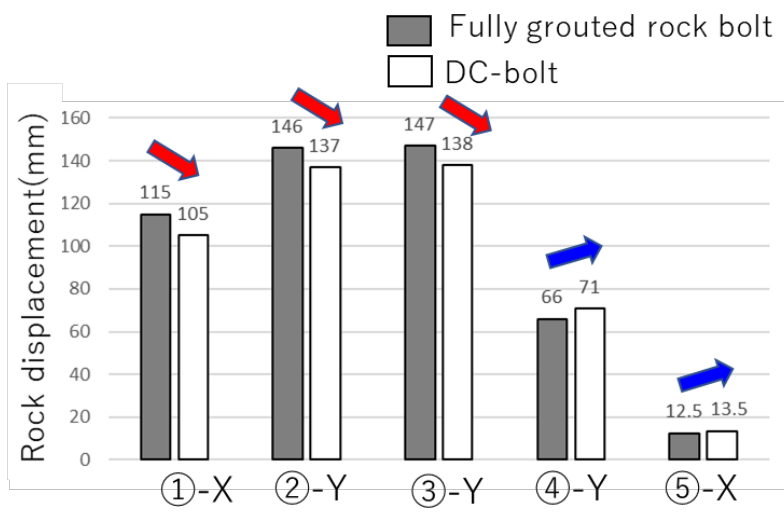

(b)

Figure 15 Monitoring result of the rock displacement: (a) monitoring locations; (b) rockbolt displacement after the excavation

\section{Summary}

In this study, the reinforcement effect of a newly developed DC-bolt was verified by DDA simulations and laboratory tests. The findings can be summarised as follows:

- In the DDA-based rockbolt pull-out simulations, distinctive behaviours in shear force and axial force distribution of the fully grouted rockbolt and the DC-bolts were observed, and the load-displacement curves were found to be well consistent with the results of laboratory pull-out tests.

- In the DDA-based tunnel excavation simulations, several fully grouted rockbolts were ruptured due to the large tunnel deformation, resulting in larger displacement (tunnel instability) and broader extent of the yielding zone. In contrast, no DC-bolts ruptured during the excavation, and the modelled tunnel displacement was restricted to that allowed by the DC-bolt-that is, the tunnel remained stable.

\section{References}

Arno, T, Patrick, S \& Markus, S 2006, 'Tunnelling in squeezing rock-yielding elements and face control', paper presented at the 8th International Conference on Tunnel Construction and Underground Structures, Slovenia, 15-17 November.

Barla, G 2001, 'Tunnelling under squeezing rock conditions', Eurosummer-School in Tunnel Mechanics, Innsbruck.

Fabbri, D 2004, 'The Gotthard Base Tunnel: Project overview', paper presented at the 6th Annual Tunnelling Conference, Sydney, 30-31 August.

Farmer, IW 1975, 'Stress distribution along a resin grouted rock anchor', International Journal of Mining Science and Technology, vol. 12, no. 11, pp. 347-351.

Hoek, E 2006, Practical Rock Engineering, Rocscience, https://www.rocscience.com/assets/resources/learning/hoek/Practical-RockEngineering-Full-Text.pdf

Jager, AJ 1992, 'Two new support units for the control of rockburst damage', in PK Kaiser \& DR McCreath (eds), Proceedings of the International Symposium on Rock Support in Mining and Underground Construction, A.A. Balkema, Rotterdam, pp. 621-631.

Kaiser, PK \& Cai M 2013, 'Critical review of design principles for rock support in burst-prone ground-time to rethink!', in Y Potvin \& B Brady (eds), Proceedings of the Seventh International Symposium on Ground Support in Mining and Underground Construction, Australian Centre for Geomechanics, Perth.

$\mathrm{Li}, \mathrm{CC}$ 2010, 'A new energy-absorbing bolt for rock support in high stress rock masses', International Journal of Rock Mechanics and Mining Sciences, vol. 47, no. 3, pp. 396-404.

Li, CC 2011, 'Performance of D-bolts under static loading', Rock Mechanics and Rock Engineering, vol. 45, no. 2, pp. $183-192$.

$\mathrm{Li}, \mathrm{CC}$ 2017, 'Principles of rockbolting design', Journal of Rock Mechanics and Geotechnical Engineering, vol. 9, no. 3, pp. 396-414.

$\mathrm{Li}, \mathrm{CC}$, Stjern, G \& Arne, M 2014, 'A review on the performance of conventional and energy-absorbing rockbolts', Journal of Rock Mechanics and Geotechnical Engineering, vol. 6, no. 4, pp. 315-327.

Ortlepp, WD 1992, 'The design of support for the containment of rockburst damage in tunnels e an engineering approach', in PK Kaiser \& DR McCreath (eds), Proceedings of the International Symposium on Rock Support in Mining and Underground Construction, A.A. Balkema, Rotterdam, pp. 593-609. 
Rehbock-Sander, M \& Jesel, T 2018, 'Fault induced rock bursts and micro-tremors-experiences from the Gothard Base Tunnel', Tunnelling and Underground Space Technology, vol. 81, pp. 358-366.

Schubert, W \& Moritz, B 1998, 'Controllable ductile support system for tunnels in squeezing Rock', Felsbau, vol. 16, no. 4, pp. 224-227.

Varden, R, Lachenicht, R, Player, J, Thompson, A \& Villaescusa, E 2008, 'Development and implementation of the Garford Dynamic 'Bolt at the Kanowna Belle Mine', Proceedings: Tenth AusIMM Underground Operators' Conference-Boom and Beyond, Australasian Institute of Mining and Metallurgy, Carlton, pp. 95-102. 